\title{
Erratum
}

\section{Thinking Ahead: Government Time Horizons and the Legalization of International Investment Agreements-ERRATUM}

\author{
Blake, D.
}

doi:10.1017/S0020818313000258, Published by Cambridge University Press, 9 October, 2013.

In the original publication of "Thinking Ahead: Government Time Horizons and the Legalization of International Investment Agreements," the link to the supplementary files was listed incorrectly. The correct link to the supplementary materials is: http://thedata.harvard.edu/dvn/dv/dblake. The publisher regrets this error.

\section{References}

Blake, D. 2013. Thinking Ahead: Government Time Horizons and the Legalization of International Investment Agreements. International Organization 67 (4):797-827. doi:10.1017/S0020818313000258. 